\title{
Light partitioning among species and species replacement in early successional grasslands
}

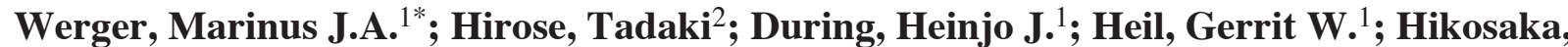 \\ Kouki²; Ito, Takehiko²; Nachinshonhor, U.G.²; Nagamatsu, Dai²; Shibasaki, Katsuhiko²; \\ Takatsuki, Seiki ${ }^{3}$; van Rheenen, Jan W. ${ }^{1}$ \& Anten, Niels P.R. ${ }^{1,2}$ \\ ${ }^{1}$ Department of Plant Ecology, Utrecht University, P.O. Box 80084, 3508 TB Utrecht, The Netherlands; ${ }^{2}$ Biological \\ Institute, Graduate School of Science, Tohoku University, Sendai 980-8578, Japan; E-mail hirose@mail.cc.tohoku.ac.jp; \\ ${ }^{3}$ The University Museum, The University of Tokyo, Hongo 7-3-1, Bunkyo-ku, Tokyo 03-0033, Japan; \\ E-mailtaka@um.u-tokyo.ac.jp; ${ }^{*}$ Corresponding author; E-mailm.j.a.werger@bio.uu.nl; Web sitewww.bio.uu.nl/ boev
}

\begin{abstract}
We studied canopy structure, shoot architecture and light harvesting efficiencies of the species (photon flux captured per unit above-ground plant mass) in a series of exclosures of different age (up to $4.5 \mathrm{yr}$ ) in originally heavily grazed grassland in N Japan.Vegetation height and Leaf Area Index (LAI) increased in the series and Zoysia japonica, the dominant in the beginning, was replaced by the much taller Miscanthus sinensis. We showed how this displacement in dominance can be explained by inherent constraints on the above-ground architecture of these two species. In all stands light capture of plants increased with their above-ground biomass but taller species were not necessarily more efficient in light harvesting. Some subordinate species grew disproportionally large leaf areas and persisted in the shady undergrowth. Some other species first grew taller and managed to stay in the better-lit parts of the canopy, but ultimately failed to match the height growth of their neighbours in this early successional series. Their light harvesting efficiencies declined and this probably led to their exclusion. By contrast, species that maintained their position high in the canopy managed to persist in the vegetation despite their relatively low light harvesting efficiencies. In the tallest stands 'later successional' species had higher light harvesting efficiencies for the same plant height than 'early successional' species which was mostly the result of the greater area to mass ratio (specific leaf area, SLA) of their leaves.

This shows how plant stature, plasticity in above-ground biomass partitioning, and architectural constraints determine the ability of plants to efficiently capture light, which helps to explain species replacement in this early successional series.
\end{abstract}

Keywords: Canopy structure; Grazing; Light acquisition efficiency; Photon flux; Plant architecture; Plant size inequality; Plasticity.

Nomenclature: Makino (1962); Ohwi (1965).

Abbreviations: LAI $=$ Leaf area index; $\mathrm{LAR}=$ Leaf Area Ratio; LMR = Leaf Mass Ratio; PPFD = Photosynthetically active photon flux density; SLA = Specific Leaf Area.

\section{Introduction}

In dense stands of vegetation photosynthetically active photon flux density (PPFD) decreases exponentially with increasing depth in the canopy (Monsi \& Saeki 1953). Consequently, plants that grow tall can deploy their foliage in the upper layers of the canopy where they capture the greater part of available PPFD while simultaneously shading shorter plants.

With increasing height, plants have to invest disproportionally more biomass in support tissues (Givnish 1982; Küppers 1985) and this reduces their Leaf Mass Ratio (LMR, the proportion of leaf mass to total aboveground mass) and, consequently, the PPFD harvested per unit amount of (above-ground) biomass decreases. Hirose \& Werger (1995) showed that the PPFD absorbed per unit amount of above-ground biomass $\left(\Phi_{\text {mass }}\right)$ was not necessarily lower in subordinate plants than in tall plants, even though the PPFD absorbed per unit leaf area $\left(\Phi_{\text {area }}\right)$ was low in the subordinate plants. Subordinate and tall, often dominant plants maintained similar light harvesting efficiencies $\left(\Phi_{\text {mass }}\right)$ by employing different above-ground biomass allocation patterns for PPFD capture, with the subordinate plants having a much higher Leaf Area Ratio per unit of above-ground biomass (LAR), mainly as a result of a higher Specific Leaf Area (SLA, leaf area per unit leaf mass), than the tall plants. These similar efficiencies may help explain how those plants of different stature are able to co-exist (Hirose \& Werger 1995; Anten \& Hirose 1999).

Without grazing and burning the species composition of many grasslands gradually shifts over time. This replacement of one set of species by another, commonly called succession, goes together with changes in the canopy structure of the vegetation: the vegetation grows taller, stand biomass and total leaf area increase, and as a consequence the light climate in the stand changes. 
This affects both dominant and subordinate species. Several species manage to grow in a number of subsequent stages of a successional series, though their growth performance may differ between those stages (Küppers 1985). One important way in which plants may be able to persist is by modifying their pattern of biomass allocation to various plant organs affecting light harvesting capacity (Schwinning \& Weiner 1998). It has been shown experimentally, that plants indeed possess some plasticity in allocating their biomass to internodes, petioles and leaves, in order to improve the amount of PPFD they can harvest in response to the light conditions under which they grow (Huber 1996, 1997; Huber \& Wiggerman 1997; Huber et al. 1998; Leeflang et al. 1998). However, this capacity is constrained by the inherent architectural pattern of their modular units of growth. In the progressively changing environment of a successional series such architectural constraints may limit a plant's growth performance and one species may be outcompeted by another; this may partly explain why shifts in species composition occur.

In this paper we investigate changes in above-ground canopy structure and species composition in the early stages of a successional series of dense grassland that grows progressively taller in reaction to the exclusion of intense grazing by deer. We calculate the amounts of PPFD harvested per unit above-ground biomass $\left(\Phi_{\text {mass }}\right)$ and per unit leaf area $\left(\Phi_{\text {area }}\right)$ by the species and analyse the shifts in these variables of several species as they are forced to grow up with the progressively taller growing vegetation and modify their morphology, in particular their LAR. We compare the 'early successional' species with the 'later successional' species on the basis of these variables. We also analyse for the two dominant species in this series how their architectural designs constrain their morphological plasticity and thus limit their occurrences in the stages of the successional series. In this way we believe to make a first, simple step towards a mechanistic explanation of species replacement.

\section{Material and Methods}

\section{Study area}

The study area is Kinkazan, Miyagi Prefecture, in northern Honshu, Japan ( $38^{\circ} 17^{\prime} \mathrm{NL}, 141^{\circ} 39^{\prime} \mathrm{EL}$ ), an island of 960 ha in the Pacific Ocean at a distance of ca. $600 \mathrm{~m}$ in front of the east coast of Japan. Its highest point lies at $445 \mathrm{~m}$. Its climax vegetation is a broad-leaved deciduous forest of Fagus crenata and Carpinus tschonoskii and a mixed evergreen needle-leaved forest of Abies firma with Carpinus tschonoskii, Zelkova serrata and Viburnum dilatatum (Miyawaki 1987).
For centuries the island of Kinkazan has fallen within the precincts of the Koganeyama Shrine. In some large patches the forest has been destroyed by natural disturbances. In a number of these patches, particularly near the Shrine, forest regeneration has been prevented by the numerous grazing sika deer (Cervus nippon) which are protected on the island and have no predators locally (Takatsuki et al. 1994). The sika deer have transformed those patches in closely cropped grazing lawns, dominated by Zoysia japonica, and they maintain them as grazing lawns for years on end.

To study the change in vegetation after exclusion of grazing, large sections of these grazing lawns of up to 1 ha in size have been fenced to exclude the deer at different times since 1990. These fenced-off sections of different ages developed into a series of vegetation types of increasing plant height and above-ground biomass, connected with a gradual shift in species composition. This situation offered an excellent opportunity to study the effects of a changing light climate on the species in an early successional series, even though there was only one large exclosure for each successional stage so that statistical analysis would provide a measure of within stage variation only and merely an indication of stage contrasts.

In the summer of 1994 we studied the following four early successional stages (see Tables 1 and 4):

\section{Zoysia japonica grazing lawn}

These Zoysia stands have a dense vegetation which was permanently and heavily grazed by sika deer, in densities of up to 600 deer. $\mathrm{km}^{-2}$ (Takatsuki et al. 1994). They kept the vegetation homogeneously low but with a good ground cover, mainly provided by the short leaves and short stems of Zoysia japonica connected by tough rhizomes. Zoysia japonica was the only dominant, but several other species occurred, all with small to tiny plants. The vegetation was up to ca. $4 \mathrm{~cm}$ tall, with a few emergent flowering stems, mainly of Zoysia, up to $8 \mathrm{~cm}$ tall.

\section{Hydrocotyle stands}

This dense grassland vegetation, ca. $30-40 \mathrm{~cm}$ tall, had developed from a Zoysia grazing lawn in the three seasons since it was fenced in late 1991. It was still strongly dominated by Zoysia japonica, and also contained much Hydrocotyle maritima (some $10 \%$ of the above-ground biomass of the stand) in the dense Zoysia turf. Other species occurred in smaller quantities.

\section{Brachypodium stands}

This tall grassland vegetation had developed out of a Zoysia grazing lawn under $4.5 \mathrm{yr}$ of exclusion of the sika deer on a somewhat dry, gentle slope. The vegetation was $60 \mathrm{~cm}$ tall. Though giving a fair ground cover, this 
vegetation was less dense than the Zoysia and Hydrocotyle stands. Miscanthus sinensis and Brachypodium sylvaticum were dominants.

\section{Miscanthus stands}

This fourth stage was a very tall, dense grassland that developed out of the Zoysia grazing lawn also under $4.5 \mathrm{yr}$ of protection from grazing, but this vegetation was growing at a damp, gentle footslope. The vegetation was $180 \mathrm{~cm}$ tall and was dominated by Miscanthus sinensis. Tall herbs (e.g. Senecio cannabifolius, Boehmeria sieboldiana) and graminoids (e.g. Calamagrostis epigeios, Carex humilis, C. japonica), shrublets (e.g. Stephanandra incisa, Rosa multiflora) and some climbers (e.g. Akebia quinata, Dioscorea japonica, Paederia scandens) also were present as well as a number of small, subordinate species, but Zoysia japonica had disappeared.

Though the Brachypodium and Miscanthus stands do not differ in length of development since deer exclusion began, they differ strongly in species composition, biomass production and canopy structure development. We assume that this is due to the edaphic differences between the sites, the Brachypodium stands being drier than the Miscanthus stands. Quite irrespective of whether these four stages form a linear successional series in terms of the development of species composition over time, in terms of canopy structure build-up they certainly can be considered a successional series.

\section{Field and laboratory methods}

In mid-summer (i.e. 5-12 July) of 1994, when the vegetation appeared to have attained about maximum yearly above-ground standing mass, we sampled the species composition, canopy structure, and light climate profiles in these four successional stages. We selected visually homogeneous stands - homogeneous regarding species composition and above-ground vegetation structure - and sampled four plots in each vegetation type. We took different plot sizes in different vegetation types, in correspondence with the coarseness of the vegetation structure. Plots in the low, dense Zoysia japonica grazing lawn measured $25 \mathrm{~cm} \times 12.5 \mathrm{~cm}$ each. The vegetation was cut out as a sod and taken to the laboratory for processing. Plots in the Hydrocotyle and in the Brachypodium vegetation types were $50 \mathrm{~cm} \times$ $12.5 \mathrm{~cm}$, and plots in the Miscanthus vegetation type were $100 \mathrm{~cm} \times 25 \mathrm{~cm}$. In all these plots the total aboveground plant material was harvested by cutting all individual shoots that were rooted in the plot area at soil surface level, except for the climbers. The climbers were sampled by collecting all their plant material that occurred inside the plot area. This was done because single climber plants frequently extended over large areas beyond the plot area while others grew into the plot area from afar. Harvested plant material was separated in small packages of plants in a position that as accurately as possible corresponded to their growing position in the field, wrapped in polyethylene sheets, and brought to the laboratory for processing.

In the laboratory the plant mass harvested from each plot was sorted to species. Plants were cut in segments ('layers') measured from their base, keeping stem and leaf inclination as similar to the field situation as possible (also for climbers). Plants were cut in segments of $2.5 \mathrm{~cm}, 5 \mathrm{~cm}, 5 \mathrm{~cm}$, and $20 \mathrm{~cm}$ high for the Zoysia, the Hydrocotyle, Brachypodium and the Miscanthus plot samples, respectively. Cut segments were separated into green and dead fractions and into stem parts, leaf parts and inflorescence parts. Petioles and sheaths were included in the stem fraction. Green leaf areas were measured with a LI-3000 leaf area meter (LI-COR, Lincoln, Nebraska). Plant material was oven-dried at $70{ }^{\circ} \mathrm{C}$ for four days and weighed. All values were calculated per $\mathrm{m}^{2}$ of soil surface area and per 'layer' and data for the four replicate plots in each of the successional stages were averaged. Leaf area and dry weights per species were used to calculate LAR (Leaf Area Ratio, leaf area per unit above-ground dry weight), LMR (Leaf Mass Ratio, leaf dry weight per unit above-ground dry weight), and SLA (Specific Leaf Area, leaf area per unit leaf dry weight).

In a few cases plants were senescent with withered leaves, or leaves were heavily damaged. As a result these plants had hardly any green leaf area left; in such cases where the leaf mass measured less than $5 \%$ of the total above-ground mass of the species, that species was excluded from the calculations. This was the case for Trisetum bifidum in the Zoysia and Hydrocotyle plots, Agrostis clavata in the Hydrocotyle and Miscanthus plots, and Brachypodium sylvaticum in the Miscanthus plots.

Since architectural design might constrain the plant's morphological plasticity (Huber 1997; Huber et al. 1998), we analysed the architecture of the two dominant species in this series, Zoysia japonica and Miscanthus sinensis, in more detail by measuring plant height, lengths of internodes and number of internodes on 10 to 60 individuals in different vegetation stages in our series.

Just before harvesting the plant mass in the plots we determined the vertical distribution of PPFD in the vegetation stands, in or next to the plots to be harvested, by using a $100-\mathrm{cm}$ long light sensor with a light-sensitive $(400-700 \mathrm{~nm}$ ) area of $10 \mathrm{~mm} \times 800 \mathrm{~mm}$ (Decagon, Pullman, WA, USA) and taking readings at various horizontal levels from the base to the top of the canopies. In the Miscanthus stands we measured at vertical 
intervals of $20 \mathrm{~cm}$ throughout canopy height; in the Hydrocotyle and Brachypodium stands every $5 \mathrm{~cm}$. In the Zoysia grazing lawn we did not measure the vertical light profile as our light sensor clearly was too coarse for measuring in this low vegetation. Relative PPFD at each level was calculated against reference PPFD measured simultaneously above the canopies with a horizontally positioned point sensor (LI-185B, LI-COR). Profiles of relative PPFD were determined in four replicates in each stand.

\section{Models and calculations}

Attenuation of PPFD through the canopies was approximated by Lambert-Beer's law (Monsi \& Saeki 1953):

$$
I=I_{0} * \operatorname{EXP}\left(-k * F_{\mathrm{w}}\right)
$$

where $F$ is the accumulative leaf area index (LAI) from the top of the canopy until depth $w ; I_{0}$ and $I$ are the PPFD on a horizontal plain above the canopy and within the canopy at depth $w$, respectively; $k$ is the coefficient of light extinction. $k$ was calculated as the slope of the linear regression of $I / I_{0}$ after logarithmic transformation on $F$.

In the Miscanthus stands we calculated $k=0.50 \pm$ $0.03 ; k$-values calculated for the Hydrocotyle and Brachypodium stands were not significantly different from that of the Miscanthus stand, but more variable. Values of approximately $k=0.50$ are very commonly found in stands dominated by grasses (Monsi \& Saeki 1953; Fliervoet 1984; Schieving et al. 1992; Hirose \& Werger 1995; Anten 1997). We therefore took $k=0.50$ for all our calculated results reported here.

PPFD harvesting per species was calculated according to the model of Hirose \& Werger (1995); PPFD absorbed by the leaves of species $i$ in the $j$ th layer in the canopy $\left(\varphi_{i j}\right)$ was calculated as

$$
\varphi_{i j}=k I_{0} \operatorname{EXP}\left(-k F_{j}\right) * \Delta f_{i j}
$$

where $\Delta f_{i j}$ is the leaf area of species $i$ in layer $j$ and $F_{j}$ is the cumulative leaf area at layer $j$. Thus $\varphi_{i j}$ can be determined from $k$ and the distribution of leaf area of each species in the canopy. Total PPFD absorbed by species $i\left(\Phi_{i}\right)$ is given by

$$
\Phi_{i}=\Sigma_{i} \varphi_{i j}
$$

Also biomass investments and efficiencies of light harvesting per species were calculated according to Hirose \& Werger (1995): fitting power equations to the relationships between photon absorption $(\Phi)$ and leaf area $(A)$, or above-ground plant mass $(M)$ gives

$$
\begin{aligned}
\Phi & =\mathrm{a} A^{\mathrm{b}} \\
& \text { and } \\
\Phi & =\mathrm{c} M^{\mathrm{d}}
\end{aligned}
$$

where $\mathrm{a}, \mathrm{b}$ c and $\mathrm{d}$ are positive constants. Dividing equation (4) by $A$ and eq. (5) by $M$ gives

$$
\begin{aligned}
& \Phi_{\text {area }}=\Phi / A=\mathrm{a} A^{\mathrm{b}-1} \\
& \text { and } \\
& \Phi_{\text {mass }}=\Phi / M=\mathrm{c} M^{\mathrm{d}-1}
\end{aligned}
$$

where $\Phi_{\text {area }}$ is the photon flux absorbed per unit leaf area defined for each species and $\Phi_{\text {mass }}$ is the photon flux absorbed per unit above-ground mass defined for each species. If $M$ is considered the investment cost to absorb photons, $\Phi$ is the benefit gained for that investment, and $\Phi_{\text {mass }}$, being the ratio of benefit to cost, can be considered an efficiency of using above-ground biomass to absorb photons. The following relationship holds between $\Phi_{\text {mass }}$ and $\Phi_{\text {area }}$ :

$$
\Phi_{\text {mass }}=\operatorname{LAR} * \Phi_{\text {area }}
$$

where LAR is the Leaf Area Ratio, the ratio of leaf area realized by the plant per unit above-ground biomass. LAR can be analysed as the product of LMR and SLA. Further details of the calculation procedure for light capture are given in Hirose \& Werger (1995).

\section{Results}

Species composition, stand characteristics and shoot architecture

There was a clear shift in species composition and species biomass along the early successional series (Table 1). As the duration of the protection against grazing by sika deer increases, the vegetation grows taller and several inherently shorter species disappear (e.g. Galium pogonanthum, Potentilla freyniana), while several taller-growing species manage to establish themselves (Tables 1 and 4). In the tallest stage, the Miscanthus stands, several tall-growing herbs, climbers, and even shrubs have established between the tall growing graminoids, as well as some inherently short species that commonly occur in shady undergrowth, such as Chamaele decumbens and Clinopodium micranthum, though the biomass of these shade-tolerant species remains relatively small. In all four successional stages seedlings of the forest trees had established and some seemed to survive and grow. 
- Light partitioning and species replacement in successional grasslands -

Table 1. Species composition and biomass $\left(\mathrm{g} \cdot \mathrm{m}^{-2}\right.$ ) (standard deviations in parentheses) in four vegetation types at Kinkazan. $\mathrm{Z}=$ Zoysia stands; $\mathrm{H}=$ Hydrocotyle stands; $\mathrm{B}=$ Brachypodium stands; $\mathrm{M}=$ Miscanthus stands. Species names are according to Makino (1962) and Ohwi (1965). The species numbers are used in Fig. 2.

\begin{tabular}{|c|c|c|c|c|c|c|c|c|c|}
\hline No. & Species & $\mathrm{Z}$ & & $\mathrm{H}$ & & B & B & $\mathrm{N}$ & M \\
\hline 1 & Cornus brachypoda & 0.38 & $(0.08)$ & & & & & & \\
\hline 2 & Gentiana zollingeri & 0.04 & $(0.05)$ & & & & & & \\
\hline 3 & Lysimachia japonica & 0.34 & $(0.40)$ & & & & & & \\
\hline 4 & Potentilla freyniana & 0.07 & $(0.11)$ & & & & & & \\
\hline 5 & Sagina japonica & 0.05 & $(0.10)$ & & & & & & \\
\hline 6 & Stellaria alsine & 0.31 & $(0.56)$ & & & & & & \\
\hline 7 & Viburnum dilatatum & 0.11 & $(0.10)$ & & & & & & \\
\hline 8 & Unknown spec. 1 & 0.02 & $(0.04)$ & & & & & & \\
\hline 9 & Galium pogonanthum & 0.01 & $(0.03)$ & 0.18 & $(0.09)$ & & & & \\
\hline 10 & Gnaphalium japonicum & 0.11 & $(0.22)$ & 0.07 & $(0.03)$ & & & & \\
\hline 11 & Luzula capitata & 3.53 & $(3.56)$ & 0.51 & $(0.12)$ & & & & \\
\hline 12 & Viola obtusa & 0.37 & $(0.46)$ & 2.15 & $(0.90)$ & & & & \\
\hline 13 & Digitaria violascens & 0.24 & $(0.48)$ & & & 2.13 & $(1.06)$ & & \\
\hline 14 & Carex japonica & 0.70 & $(0.61)$ & & & & & 13.34 & $(11.06)$ \\
\hline 15 & Festuca rubra & 6.65 & $(3.75)$ & 4.54 & $(2.12)$ & 10.29 & $(1.78)$ & & \\
\hline 16 & Hydrocotyle maritima & 0.37 & $(0.49)$ & 27.78 & $(1.32)$ & 7.80 & $(1.08)$ & & \\
\hline 17 & Liriope minor & 1.67 & (1.16) & 8.29 & $(0.70)$ & 4.06 & $(0.69)$ & & \\
\hline 18 & Zoysia japonica & 133.79 & $(56.88)$ & 357.01 & $(13.64)$ & 12.24 & $(1.23)$ & & \\
\hline 19 & Agrostis clavata & 2.13 & (1.39) & 15.31 & $(2.54)$ & 0.78 & $(0.27)$ & 1.15 & $(1.87)$ \\
\hline 20 & Brachypodium sylvaticum & 0.17 & $(0.22)$ & 2.03 & $(0.49)$ & 54.24 & $(2.64)$ & 0.08 & $(0.19)$ \\
\hline 21 & Trisetum bifidum & 0.12 & $(0.24)$ & 8.68 & (2.04) & 0.70 & $(0.22)$ & 0.57 & (1.14) \\
\hline 22 & Agropyron ciliare & & & 4.76 & $(2.38)$ & & & & \\
\hline 23 & Erigeron canadensis & & & 0.05 & $(0.01)$ & & & & \\
\hline 24 & Oxalis corniculata & & & 6.15 & $(0.30)$ & & & & \\
\hline 25 & Spiranthes sinensis & & & 0.12 & $(0.01)$ & & & & \\
\hline 26 & Polygala japonica & & & 0.86 & $(0.36)$ & 0.35 & $(0.15)$ & & \\
\hline 27 & Carpinus tschonoskii & & & 0.68 & $(0.14)$ & & & 0.01 & $(0.02)$ \\
\hline 28 & Abies firma & & & 0.76 & $(0.07)$ & 0.03 & $(0.02)$ & 0.02 & $(0.04)$ \\
\hline 29 & Carex humilis & & & 2.78 & $(0.69)$ & 8.94 & $(1.42)$ & 37.85 & $(9.64)$ \\
\hline 30 & Zelkova serrata & & & 0.90 & $(0.13)$ & 0.28 & $(0.11)$ & 0.04 & $(0.08)$ \\
\hline 31 & Haloragis micrantha & & & & & 0.23 & $(0.05)$ & & \\
\hline 32 & Hypericum japonicum & & & & & 0.33 & $(0.16)$ & & \\
\hline 33 & Ixeris stolonifera & & & & & 0.18 & $(0.09)$ & & \\
\hline 34 & Ophioglossum petiolatum & & & & & 0.05 & $(0.03)$ & & \\
\hline 35 & Unknown spec. 2 & & & & & 0.01 & $(0.01)$ & & \\
\hline 36 & Calamagrostis epigeios & & & & & 0.36 & $(0.18)$ & 51.28 & $(31.11)$ \\
\hline 37 & Miscanthus sinensis & & & & & 135.13 & $(14.64)$ & 768.14( & $(306.37)$ \\
\hline 38 & Agrimonia nipponica & & & & & & & 0.14 & $(0.27)$ \\
\hline 39 & Akebia quinata & & & & & & & 3.12 & $(6.18)$ \\
\hline 40 & Boehmeria sieboldiana & & & & & & & 0.99 & (1.98) \\
\hline 41 & Caryopteris divaricata & & & & & & & 3.06 & (4.53) \\
\hline 42 & Chamaele decumbens & & & & & & & 0.25 & $(0.28)$ \\
\hline 43 & Cirsium amplexifolium & & & & & & & 5.07 & (7.67) \\
\hline 44 & Clinopodium micranthum & & & & & & & 0.00 & $(0.01)$ \\
\hline 45 & Desmodium oxyphyllum & & & & & & & 0.14 & $(0.28)$ \\
\hline 46 & Dioscorea japonica & & & & & & & 15.85 & $(17.20)$ \\
\hline 47 & Galium trachyspermum & & & & & & & 0.06 & $(0.07)$ \\
\hline 48 & Geranium thunbergii & & & & & & & 0.01 & $(0.02)$ \\
\hline 49 & Paederia scandens & & & & & & & 3.51 & $(2.82)$ \\
\hline 50 & Polygonum filiforme & & & & & & & 0.84 & $(1.10)$ \\
\hline 51 & Rosa multiflora & & & & & & & 2.23 & $(4.46)$ \\
\hline 52 & Senecio cannabifolius & & & & & & & 28.95 & $(28.03)$ \\
\hline 53 & Stephanandra incisa & & & & & & & 8.97 & (17.93) \\
\hline 54 & Unknown spec. 3 & & & & & & & 0.12 & $(0.25)$ \\
\hline
\end{tabular}

Most conspicuous is the shift in dominance as the vegetation grows taller. While Zoysia japonica overwhelmingly dominates the Zoysia and Hydrocotyle stands, it has strongly declined in the taller Brachypodium stands and has disappeared from the very tall and dense Miscanthus stands. Brachypodium sylvaticum is scarce and tiny in the Zoysia stands, has increased to subdominance in the Brachypodium stands, but has virtually disappeared from the very tall Miscanthus stands. A similar response is shown by Hydrocotyle maritima which has its highest biomass in the Hydrocotyle stands. Some Miscanthus sinensis seedlings get established in the grazing lawn but this species does not tolerate heavy grazing; under protection from grazing, however, it soon reaches full dominance. A number of narrowleaved rosette plants, such as Liriope minor, Carex humilis and Calamagrostis epigeios, profit from the cessation of grazing as they can stretch their leaves to surprising lengths in dense and tall growing vegetation (Tables 1 and 4). Other species were moderately or 
Table 2. Number of species, total above-ground biomass $\left(\mathrm{g} \cdot \mathrm{m}^{-2}\right)$, leaf area index $\left(\mathrm{m}^{2} \cdot \mathrm{m}^{-2}\right)$ and maximal canopy height $(\mathrm{cm})$ of four vegetation types at Kinkazan. Standard errors in parentheses.

\begin{tabular}{|c|c|c|c|c|c|c|c|c|}
\hline & $\mathrm{Z}$ & & $\mathrm{H}$ & & B & & M & \\
\hline Number of species & 21 & & 20 & & 19 & & 27 & \\
\hline Total above-ground biomass & 150.8 & $(28.5)$ & 443.6 & $(6.5)$ & 238.1 & $(7.6)$ & 945.6 & $(148.6$ \\
\hline Leaf Area Index & 1.55 & $(0.20)$ & 3.91 & $(0.10)$ & 1.82 & $(0.19)$ & 6.05 & $(0.73)$ \\
\hline Maximal canopy height & 7.5 & & 40 & & 65 & & 180 & \\
\hline
\end{tabular}

strongly limited in the maximum leaf height they could achieve when the vegetation grew taller (e.g. Agrostis clavata, Zoysia japonica, Hydrocotyle maritima, Luzula capitata, and particularly so Viola obtusa and Potentilla freyniana - which reaches $5 \mathrm{~cm}$ only).

Total above-ground biomass, total LAI and maximum canopy height measured in the plots are given in Table 2.

The shoots of the two dominant species, Zoysia japonica and Miscanthus sinensis, differed very much in their architectural design and in the plasticity thereof (Table 3). Zoysia always grew a very limited number of internodes from which leaves emerged before producing a terminal inflorescence. In the grazing lawn the internodes were extremely short, particularly so the internodes above the basal internode, and in the taller stands these internodes could increase more than ten fold in length but nevertheless stayed short relative to several other species. The result was that Zoysia could not reach more than $30 \mathrm{~cm}$ in height and often reached less. In the Zoysia stands there was no correlation between the number of internodes and total stem height of Zoysia $\left(r^{2}=0.1936\right)$ nor maximum leaf height $\left(r^{2}=\right.$ 0.2809) but in the Brachypodium stands Zoysia stem height was positively correlated with the number of internodes $\left(r^{2}=0.4319 ; p<0.01\right)$, while maximum leaf height was not $\left(r^{2}=0.1399\right)$. Miscanthus, on the contrary, could not grow short internodes: the basal internode was nearly $8 \mathrm{~cm}$, the other internodes were around $11 \mathrm{~cm}$ or longer and the plants could grow many internodes before producing the terminal inflorescence. With this growth habit Miscanthus could reach the highest position in the canopy. With 15 or more internodes it could reach a leaf height of more than $2.5 \mathrm{~m}$ in full growth. The number of internodes significantly correlated with total stem height $\left(r^{2}=0.9274 ; p<0.01\right)$ and maximum leaf height $\left(r^{2}=\right.$ $0.6956 ; p<0.01)$.

\section{Partitioning of PPFD and leaf area patterns}

In all stands the amount of photons absorbed linearly increased with the above-ground biomass of the species (Fig. 1a). In all stands species also differed in the amount of photons harvested per unit of above-ground biomass $\left(\Phi_{\text {mass }}\right)$. However, only in the Miscanthus stands there was a significant positive relation between $\Phi_{\text {mass }}$ and total above-ground mass of the species, i.e. only in this stand the slope ( $d$ in Eq. 5) in the linear regression of $\log \Phi$ on $\log$ mass was significantly greater than 1 (Studentized $t$ test $p<0.05$ ). For the same plant mass, shoots in the Miscanthus stands had significantly lower $\Phi_{\text {mass }}$ than shoots in the other stands (Based on ANCOVA with logtransformed $\Phi$ and mass and plots as dependent variable, covariate and factor, respectively, $p<0.0001$, Fig. 1b). In this dense and tall-growing Miscanthus vegetation the stratification of species over the total canopy height was most strongly developed: the tallest species nearly had the highest light harvesting efficiency, reached the top of the canopy and contributed most to the biomass of the stand (Figs. 1, 2a-d; Table 1, 4). In the other, earliersuccessional stages the tallest-growing species were not necessarily the most efficient in terms of biomass expenditure for light harvesting (Fig. 2a-d; Table 4). Highest efficiencies were found in some rosette species in the shortest vegetation type (e.g. Potentilla freyniana, Viola obtusa, Brachypodium sylvaticum, Gnaphalium japonicum). In the somewhat taller vegetation, the trailing Galium pogonanthum, the creeping Hydrocotyle maritima which can extend its petioles to lift its leaf blades higher in the canopy, the erect but rather short Oxalis corniculata and

Table 3. Architectural characteristics of Zoysia japonica and Miscanthus sinensis in different stands (standard errors in parentheses).

\begin{tabular}{|c|c|c|c|c|}
\hline Variable & $\begin{array}{l}\text { Zoysia in } \\
\text { grazing lawn }\end{array}$ & $\begin{array}{c}\text { Zoysia in } \\
\text { Brachypodium } \\
\text { stand }\end{array}$ & $\begin{array}{l}\text { Miscanthus in } \\
\text { Brachypodium } \\
\text { stand }\end{array}$ & $\begin{array}{l}\text { Miscanthus in } \\
\text { Miscanthus } \\
\text { stand }\end{array}$ \\
\hline$n$ & 36 & 60 & 10 & 10 \\
\hline Maximum leaf height (cm) & $3.0 \quad(0.2)$ & $(0.6)$ & $(3.8)$ & $(8.7)$ \\
\hline Stem height $(\mathrm{cm})$ & $1.2 \quad(0.07)$ & $(0.8)$ & $(2.5)$ & $(3.7)$ \\
\hline \# of internodes & $4.4 \quad(0.3$ & $(0.5)$ & $(0.3)$ & $(0.4)$ \\
\hline Length of basal internode $(\mathrm{cm})$ & $0.9 \quad(0.05)$ & $(0.1)$ & $(1.3)$ & $(0.7)$ \\
\hline Length of other internodes (cm) & $0.1 \quad(0.02)$ & $(0.2)$ & $(0.5)$ & $(0.9)$ \\
\hline
\end{tabular}



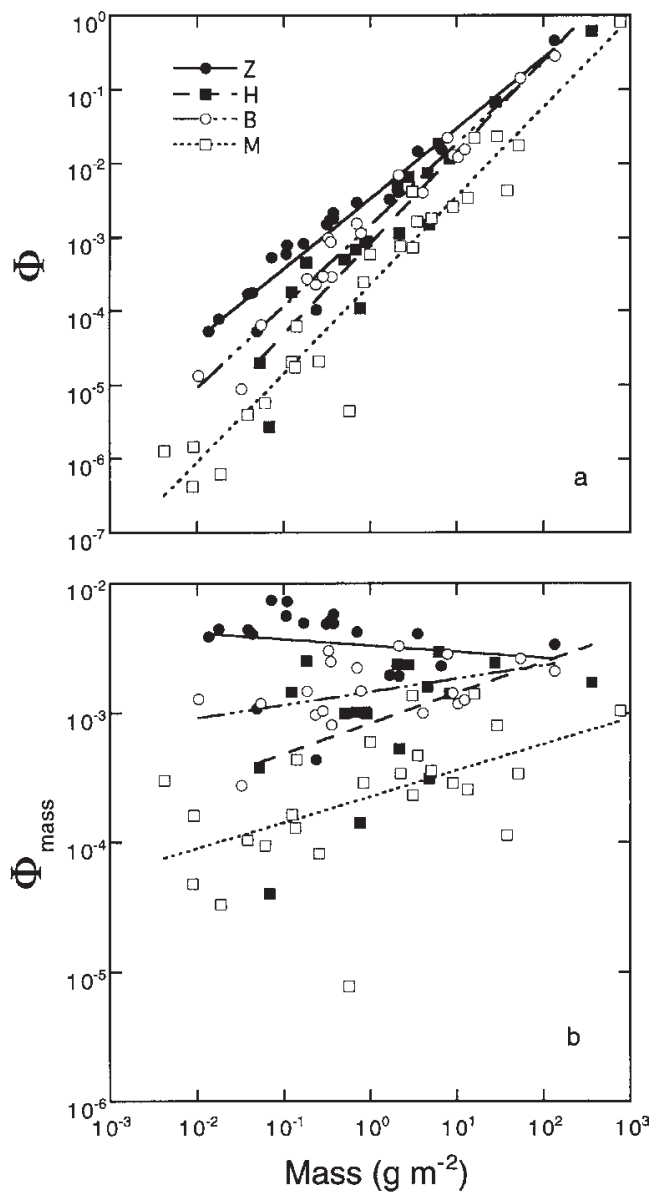

Fig. 1. $\Phi$ against species mass (a) and $\Phi_{\text {mass }}$ against species mass (b) in four early successional vegetation types at Kinkazan. $\mathrm{Z}=$ Zoysia stands $; \mathrm{H}=$ Hydrocotyle stands $; \mathrm{B}=$ Brachypodium stands; $\mathrm{M}=$ Miscanthus stands. In Fig. 1b only the correlation for the Miscanthus stands is significant $(p<0.01)$.

the long-leaved rosette plants Brachypodium sylvaticum and Carex humilis also reached great efficiencies. In the still taller Brachypodium stands Brachypodium sylvaticum still managed to reach a relatively great efficiency although biomass turnover seemed large as indicated by the rather large amount of dead Brachypodium leaves low in the canopy. The grass Digitaria violascens and the slender, erect herb Hypericum japonicum also reached high $\Phi_{\text {mass }}$ values but all these species did not reach the top of the canopy formed by Miscanthus sinensis. In the very tall Miscanthus stands the highest efficiencies were realized by the herbaceous climber Dioscorea japonica, the tall herbs (e.g. Caryopteris divaricata, Boehmeria sieboldiana, Senecio cannabifolius) and Miscanthus sinensis. Clinopodium micranthum, a short species of the undergrowth in the tall Miscanthus vegetation, also realized a relatively high efficiency and in this way it can persist low in the canopy (Fig. 2; Table 4).
In general, species that occurred in more than one stand type used more biomass to harvest the same amount of light as they grew taller in the taller vegetation canopies of this early successional series, and thus declined in their light-harvesting efficiencies. This decline may partly result from a shift in biomass investment pattern towards more support tissue, but it was mainly caused by limitations on the height growth potentials: the taller-growing species overtopped the stature-limited species and confined them to deeper parts of the canopy where there is less light available. This pattern was clearly shown by Zoysia japonica, Hydrocotyle maritima, Carex humilis, Liriope minor, Festuca rubra, Viola obtusa, etc. (Table 4). Only two species showed another pattern in the relation between vegetation height, plant height and $\Phi_{\text {mass }}$ : Digitaria violascens and Polygala japonica (Table 4). However, Digitaria violascens in the Zoysia stands consisted of short stems with small remnants of the long, grazed-off leaves, which explains its low $\Phi_{\text {mass }}$ value there. Polygala japonica differs from all other species in the stands in that it is an evergreen species with very tiny leaves along the lower parts of its stems and about three times larger leaves along the higher stem parts; this may lead to higher $\Phi_{\text {mass }}$ values in taller plants.

We investigated whether 'early successional' species in this successional series differ in terms of efficiency from 'later successional' species. We separated the species in the Miscanthus stands into two groups: species that also occurred in the Zoysia and/or Hydrocotyle, and/ or Brachypodium stands (= 'early successional' species) and species that only occurred in the Miscanthus stands ('later successional' species). The 'later successional' species tended to have greater efficiencies for the same plant height than the 'early successional' species ( $p=$ 0.056; Table 5) and they also tended to reach greater heights (Fig. 2d). The exception to this were a few 'later successional', low, shade-tolerant undergrowth species with relatively low efficiencies (Chamaele decumbens, Geranium thunbergii, Galium trachyspermum, Agrimonia nipponica; Fig. 2d).

Species also differed in the amount of photons harvested per unit of their leaf area. Except for the Zoysia stands there was a significant positive relationship between $\Phi_{\text {area }}$ and total leaf area of the species (data not shown) and a strong increase of $\Phi_{\text {area }}$ with plant height, stronger than the increase of $\Phi_{\text {mass }}$ with plant height (Fig. 3a, Fig. 2). Thus, within stands there was a negative relationship between $\Phi_{\text {area }}$ and LAR.

In all stands the range in LAR values changed ca. ten-fold between species and overlapped completely between stands (Fig. 3b). Within stands LAR tended to decrease with plant height. Species that occurred in more than one stand type showed within-species differ- 


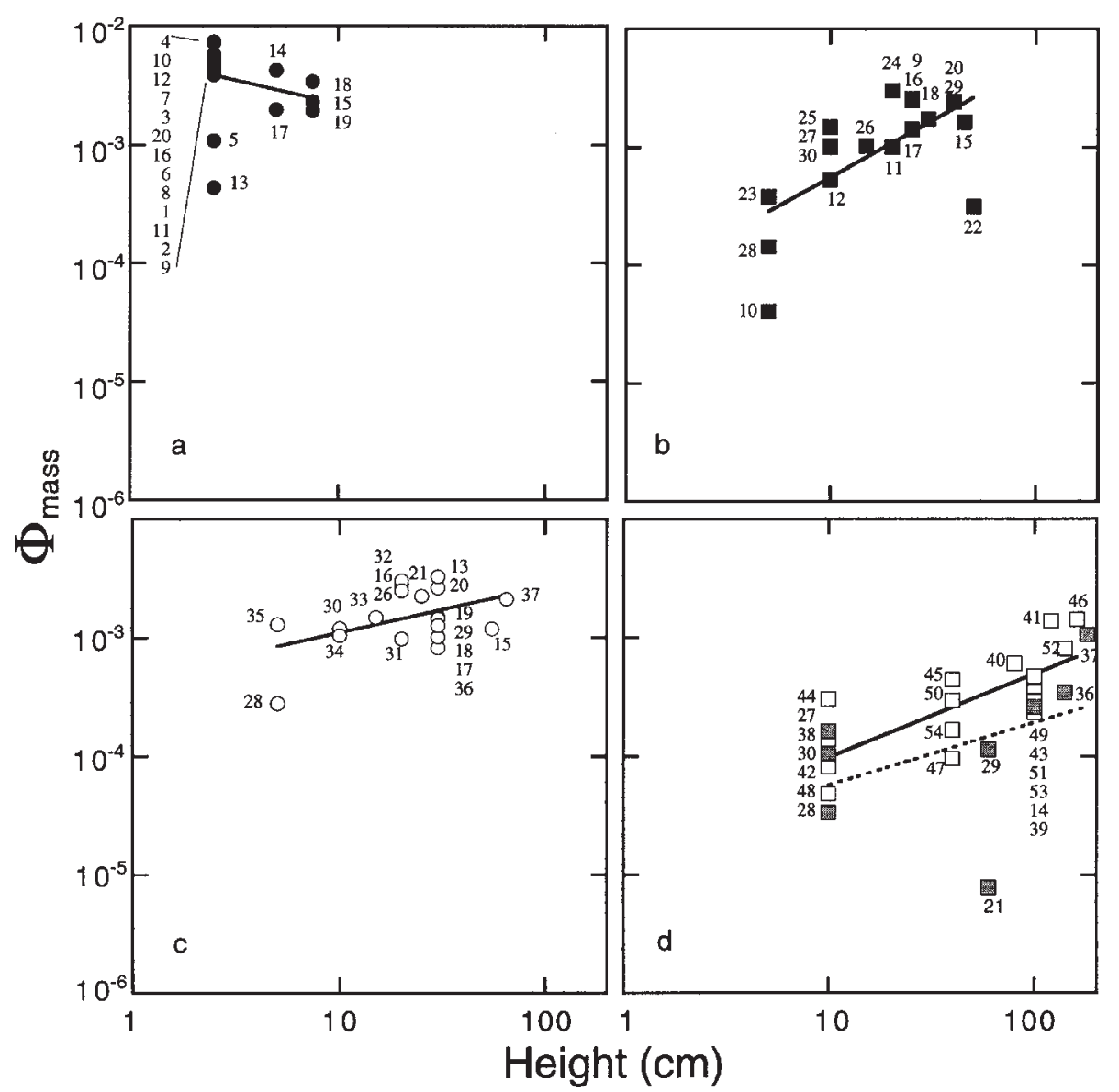

Fig. 2. $\Phi_{\text {mass }}$ against greatest plant height in the four successional stages at Kinkazan. Numbers refer to species as given in Table 1 . a. Zoysia stands; correlation N.S.; b. Hydrocotyle stands; correlation significant at $p<0.05$; c. Brachypodium stands; correlation N.S.; d. Miscanthus stands. In the Miscanthus stands the 'early successional species' (see text for explanation) are shaded. Correlation for the 'later successional species' significant at $p<0.01$ (solid line); for the 'early successional species' at $p<0.05$ (broken line). Intercepts of these two regression lines are significantly different $(p=0.019)$.

Table 4. Values of plant height $(\mathrm{cm})$ and $\Phi_{\text {mass }}(\times 10000)$ for species that occur in more than one stand type. The canopy height of the stand types is also indicated.

\begin{tabular}{|c|c|c|c|c|c|c|c|c|}
\hline $\begin{array}{l}\text { Stand type } \\
\text { Stand height }(\mathrm{cm})\end{array}$ & $\begin{array}{c}\text { Zoysia } \\
7.5\end{array}$ & & $\begin{array}{c}\text { Hydrocotyle } \\
40\end{array}$ & & $\begin{array}{c}\text { Brachypodium } \\
65\end{array}$ & & $\begin{array}{c}\text { Miscanthus } \\
180\end{array}$ & \\
\hline & $\begin{array}{c}\text { Plant leaf } \\
\text { height }(\mathrm{cm})\end{array}$ & $\Phi_{\text {mass }}$ & $\begin{array}{c}\text { Plant leaf } \\
\text { height }(\mathrm{cm})\end{array}$ & $\Phi_{\text {mass }}$ & $\begin{array}{c}\text { Plant leaf } \\
\text { height }(\mathrm{cm})\end{array}$ & $\Phi_{\text {mass }}$ & $\begin{array}{c}\text { Plant leaf } \\
\text { height }(\mathrm{cm})\end{array}$ & $\Phi_{\text {mass }}$ \\
\hline Galium pogonanthum & 2.5 & 39.10 & 25 & 25.38 & & & & \\
\hline Gnaphalium japonicum & 2.5 & 72.61 & 5 & 0.40 & & & & \\
\hline Luzula capitata & 2.5 & 41.18 & 20 & 9.99 & & & & \\
\hline Viola obtusa & 2.5 & 58.20 & 10 & 5.31 & & & & \\
\hline Digitaria violascens & 2.5 & 4.37 & & & 30 & 33.11 & & \\
\hline Carex japonica & 5 & 42.59 & & & & & 100 & 2.59 \\
\hline Festuca rubra & 7.5 & 23.20 & 40 & 16.21 & 55 & 11.89 & & \\
\hline Hydrocotyle maritima & 2.5 & 49.29 & 25 & 24.68 & 20 & 9.77 & & \\
\hline Liriope minor & 5 & 19.86 & 25 & 14.17 & 30 & 10.11 & & \\
\hline Zoysia japonica & 7.5 & 34.14 & 30 & 17.29 & 30 & 12.66 & & \\
\hline Agrostis clavata & 7.5 & 19.44 & & & 30 & 14.95 & & \\
\hline Brachypodium sylvaticum & 2.5 & 49.87 & 40 & 24.11 & 35 & 26.55 & & \\
\hline Polygala japonica & & & 15 & 10.22 & 20 & 25.12 & & \\
\hline Carex humilis & & & 40 & 23.85 & 25 & 14.43 & 60 & 1.14 \\
\hline Calamagrostis epigeios & & & & & 30 & 8.18 & 140 & 3.42 \\
\hline Miscanthus sinensis & & & & & 65 & 21.20 & 180 & 10.48 \\
\hline
\end{tabular}



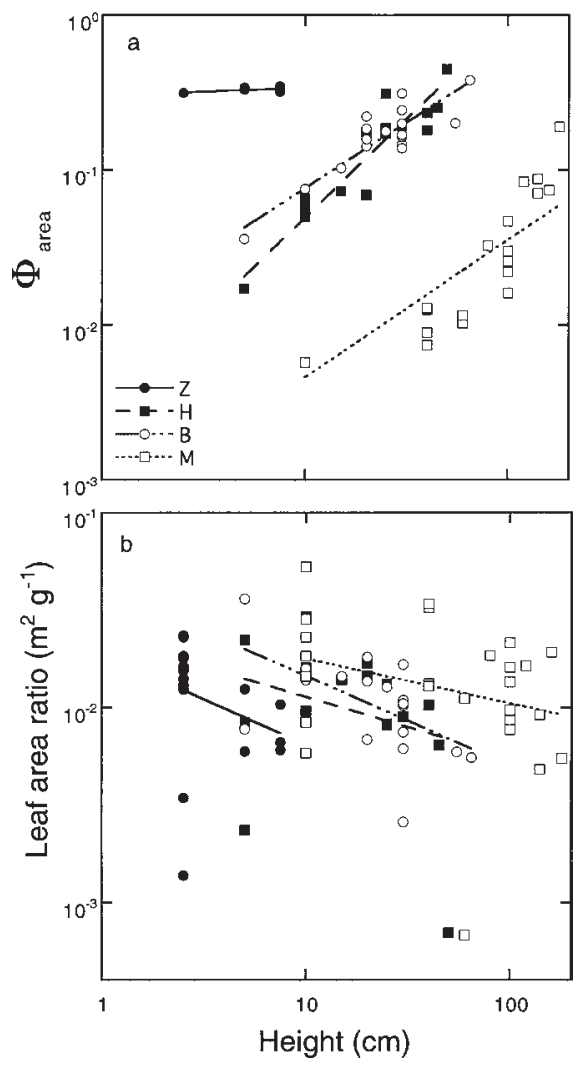

Fig. 3. $\Phi_{\text {area }}$ and Leaf Area Ratio against plant height. Symbols as in Fig. 1. Correlations in Fig. 3a are all significant at $p$ $<0.01$. In Fig. 3b correlations for the Zoysia and Brachypodium stands are significant at $p<0.05$, and not significant $(p<0.1)$ for the Hydrocotyle stands and the Miscanthus stands.

ences in LAR, but this was always less than two-fold.

LMR values also changed about ten-fold between species and did not show a clear relation with plant height, though there was an overall negative trend. SLA decreased with light availability ( $\left.\Phi_{\text {area }}\right)$ (data not shown). In the Miscanthus stands LAR values decreased with plant height but the 'early successional' species had significantly lower LAR values for the same plant height than 'later successional' species (Fig. 4a, Table 5). This difference in LAR between 'early' and 'later successional' species was entirely due to a corresponding difference in SLA values (Fig. 4b, Table 5).

Table 5. ANCOVA results of $\Phi_{\text {mass }}$, LAR and SLA against plant height of 'early successional' species and 'later successional' species (* $=$ significant difference).

\begin{tabular}{llll}
\hline Dependent & Co-variate & Slope & Intercept \\
\hline$\Phi_{\text {mass }}$ & Plant height & 0.644 & 0.056 \\
LAR & Plant height & 0.564 & $0.022^{*}$ \\
SLA & Plant height & 0.254 & $0.003^{*}$ \\
\hline
\end{tabular}

\section{Discussion}

Traditionally vegetation scientists, when studying succession processes, focus on shifts in species composition in a time series, or in a spatial zonation, of stands of vegetation and describe succession as a series of species replacements. Attempts to explain the course of succession are often given in terms of life history attributes (Miles 1979; Noble \& Slatyer 1980; Huston \& Smith 1987; Glenn-Lewin et al. 1992; Prach et al. 1997). Species replacements result from differences in species performances at a site which can lead to competitive exclusions. A plant's performance in dense stands of vegetation is affected by the functioning of neighbouring plants and by its inherent plasticity to respond to the environmental conditions developing in the stand. In responding to those environmental conditions developing in a growing dense stand plants may adapt their physiological

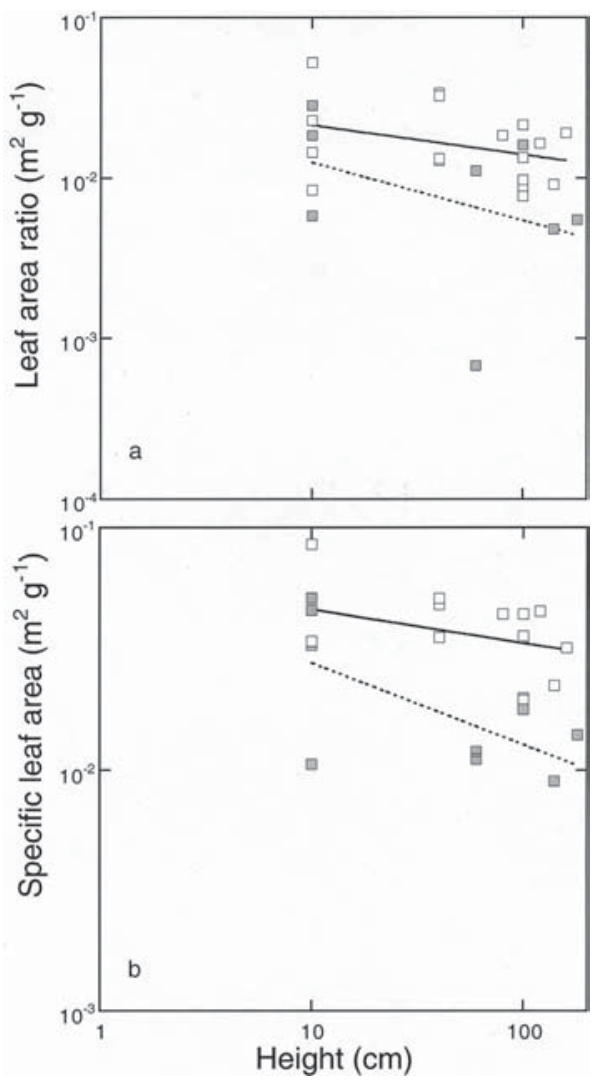

Fig. 4. Leaf Area Ratio (a) and Specific Leaf Area (b) against plant height in the Miscanthus stands. 'Early successional species' (shaded, broken line) and 'later successional species' (white, solid line) are separately analysed. See text for explanation. Correlations are significant at $p<0.05$, slopes are not significantly different and intercepts are significantly different at $p<0.01$. 
mechanisms, e.g. at the level of their leaves or roots, and they may change their allocation pattern to various plant organs and their morphology (e.g. SLA, internode length). Generally, adaptation of the allocation pattern appears much more important in determining the competitive interaction than adaptation of the physiological mechanisms (Pearcy et al. 1981; Küppers 1984, 1985; Barnes et al. 1990; Schwinning \& Weiner 1998; Anten \& Hirose 2001).

Competition between plants in a beginning successional series involves several resources but in dense stands competition for light appears important. In competing for light in dense stands differences in plant stature may play a decisive role (Wilson 1988; Anten \& Werger 1996). Experimental and modelling studies have shown that plants that overtop their neighbours and display sufficient leaf area in the better-lit parts of the stand's canopy are usually the dominants in a stand (Fliervoet 1984; Hirose \& Werger 1995; cf. Mitchley \& Willems 1995). To achieve this, biomass allocation patterns and associated light harvesting capacities are important (Küppers 1985; Hirose \& Werger 1995; Anten \& Hirose 1999). If constraints in plant stature do not allow a plant to reach the better-lit parts of the canopy, it may still be able to survive and grow under light-limiting conditions low in the canopy. Here physiological mechanisms and plant morphologies allowing for increased light harvesting capacities play a role (Küppers 1984, 1985; Anten \& Hirose 1999).

Thus, several plant traits may affect a plant's performance and determine its position and success or exclusion in our beginning successional series. In our explanation we mention three traits: the plant's plasticity in its pattern of biomass partitioning, the plant's architecture, and the plant's ability to survive as a subordinate in the lightlimited undergrowth.

We used Lambert-Beer's law to describe the light distribution in the vegetation canopies and calculate the light harvesting capacities of the species. This is a simple model that gives a reasonably accurate description of the average light climate over the day in a vegetation canopy (Monsi \& Saeki 1953; Werger \& Hirose 1991; Anten 1997; De Pury \& Farquhar 1997). Taking variation in leaf angles into account would have affected our results, but not drastically (Barnes et al. 1990; Anten 1997; Hikosaka \& Hirose 1997). Particularly some short, subordinate species low in the canopies of some stands had more horizontal leaves and this would result in somewhat higher $\Phi_{\text {mass }}$ values (Anten \& Hirose 1999).

We found no relation (with the exception of the Miscanthus stands) between $\Phi_{\text {mass }}$ and total above-ground biomass, and tallest species were not necessarily most efficient in terms of biomass expenditure for light harvesting (Figs. 1b, 2). In fact, in the tallest vegetation $\Phi_{\text {mass }}$ was generally lowest. This was also found in other studies (Hirose \& Werger 1995; Anten \& Hirose 1998).

In the Zoysia stands, where the canopy was very shallow and most leaves appeared to be well illuminated, variation in $\Phi_{\text {area }}$ between species was obviously small, but $\Phi_{\text {mass }}$ differed considerably between species. This indicated that some species use considerably more biomass than others to harvest the same amount of photons. In the other, taller-growing stands, which developed a steadily deeper shade lower in the canopy, light availability did play an important role in organizing the canopy: variation in $\Phi_{\text {area }}$ between species was larger and $\Phi_{\text {area }}$ and total leaf area were positively related, as also found in other studies (Hirose \& Werger 1995; Anten \& Hirose 1999). Particularly the increase of $\Phi_{\text {area }}$ with plant height was steep, showing that in tall and dense stands small differences in plant stature may have strong effects on plant performance. In monospecific stands such initial size hierarchies will be difficult to reverse (Schmitt et al. 1986; Weiner \& Thomas 1986; Wilson 1988; Nagashima et al. 1995; Anten \& Werger 1996; Anten \& Hirose 1998; Hikosaka et al. 1999).

As expected, within stands LAR values of several species decreased as species grew taller (Fig. 3b). This resulted from the taller species spending more biomass on support tissue (stems), and they also tended to have thicker leaves (their SLA values were lower). It is an important finding that the 'later successional' species (in the Miscanthus plots), at the same plant height and position in the light gradient, had higher LAR values, due to higher SLA at equal LMR values, than the "early successional' species (Fig. 4a, b, Table 5). Their biomass expenditure for light harvesting was therefore more efficient and their relative growth rates potentially higher (cf. Küppers 1985).

We have argued that plasticity in height growth as well as plasticity in the pattern of biomass allocation may be important features determining the success of a species in the changing environment of a successional series. While LAR in plants of the same species occurring in different stages of this successional series varied always less than two-fold, plasticity in LAR was not totally unimportant. This was shown by the decrease in LAR in most species when growing in taller vegetation and it was also indicated by the higher LAR values, as a result of their higher SLA values, in the 'later successional' species in the Miscanthus stands.

We conclude, however, that the species in our stands generally were more plastic in the height range they can cover than in their proportional biomass allocation to leaf area. This was also found by Anten \& Hirose (1999) and corresponds with the results of a field experiment in which vegetation height was manipulated (Huber \& Wiggerman 1997) and of a greenhouse experiment with 
different shading treatments (Leeflang et al. 1998).

Plasticity in height growth thus seemed to be an important plant feature in determining the success of a plant species as it often allowed them to maintain a rather efficient biomass expenditure in terms of light harvesting (Table 4). But there are constraints to this plant feature as a result of plant architecture. This was clearly shown by the performance of the two most abundant species in this successional series: Zoysia japonica and Miscanthus sinensis. While Zoysia japonica strongly dominated under the heavy grazing regime by the sika deer and in the very early successional stages, Miscanthus sinensis gradually took over once grazing was excluded and it dominated the later successional stages. This does not result from a grazing preference of the sika deer for Miscanthus; they eat both Miscanthus and Zoysia (Takatsuki 1978, 1980). Miscanthus also was not necessarily more efficient in light harvesting than Zoysia. Miscanthus took over because it can grow taller. In the grazing lawn Zoysia persists so well because it can make itself very small with its extremely short internodes (Table 3), it can grow its leaves under nearly horizontal angles, it continuously produces new leaves, and it has robust buds and stems that apparently are well resistant to the deer's tread. In the Hydrocotyle and Brachypodium stands Zoysia grew taller, up to a maximum of $30 \mathrm{~cm}$. This was sufficient to position its leaves in the top of the canopy of the Hydrocotyle stands, and thus it maintained a high photon flux capture. But it was about its maximum height, and the inherently short internodes did not allow Zoysia to match the stature of still taller species in the Brachypodium stands, e.g. Festuca rubra and Miscanthus sinensis (Fig. 2c, Table 4). As the vegetation still grew taller as the Miscanthus stage was approaching, Zoysia clearly was not able to survive as a subordinate species in the light-limited undergrowth: It had yellow, dead leaves along its basal stem parts in the Hydrocotyle and Brachypodium stands, and it had completely disappeared from the tall Miscanthus stands.

The question then remains: why did Miscanthus not dominate, and in fact was even scarce, in the grazing lawn? This is also a result of a constraint of its architecture: it cannot grow short, and as a consequence it does not survive heavy grazing. Miscanthus is not able to grow short internodes (Table 3), nor can it grow its leaves at nearly horizontal angles. Because Miscanthus inherently grows relatively long internodes, it perpetually loses meristems under heavy grazing and cannot replace its lost leaves sufficiently fast. Once grazing was excluded, however, Miscanthus plants could rapidly outgrow other species and overtop these. They did capture large amounts of photons, grew fast, and gained dominance (Table 4).

This is not a steady state situation, however. Among the species that invaded and maintained themselves in these early successional stages there are woody climbers and shrubs. It may be expected that within a few years precisely such woody climbers (Akebia quinata) and shrubs (Rosa multiflora, Stephanandra incisa) will manage to become dominant: they have the advantage of starting their leaf growth year after year at a higher level in the canopy because of their perennial woody stems. That will enable them to overtop the herbaceous species and pre-empt the available PPFD for their own benefit. Miscanthus is not shade-tolerant, and being overshaded it will diminish in vigour and ultimately disappear from the vegetation. The vegetation will then become a dense scrub with climbers and some shade-tolerant undergrowth species. It is virtually certain that succession still will proceed and that the scrub will develop in forest vegetation. In nearly all our samples we found small seedlings of tree species (Abies firma, Carpinus tschonoskii, Cornus brachypoda, Zelkova serrata). They run a high risk of dying off in the shady conditions deep inside the taller vegetation canopies. But some we expect to persist and grow and gradually get more advantage of their ever increasing leaf height on their progressively taller stems. With time they will dominate the canopy and build the forest.

Acknowledgements. MJAW gratefully acknowledges financial support for this study from the Japan Society for the Promotion of Science, JSPS. We sincerely thank the Koganeyama Shrine on Kinkazan for providing facilities and accommodation during the fieldwork.

\section{References}

Anten, N.P.R. 1997. Modelling canopy photosynthesis using parameters determined from simple non-destructive measurements. Ecol. Res. 12: 77-88.

Anten, N.P.R. \& Hirose, T. 1998. Biomass allocation and light partitioning among dominant and subordinate individuals in Xanthium canadense stands. Ann. Bot. 82: 665-673.

Anten, N.P.R. \& Hirose, T. 1999. Interspecific differences in above-ground growth patterns result in spatial and temporal partitioning of light among species in a tall-grass meadow. J. Ecol. 87: 583-597.

Anten, N.P.R. \& Hirose, T. 2001. Limitations on photosynthesis of competing individuals in stands and consequences for canopy structure. Oecologia 129: 186-196.

Anten, N.P.R. \& Werger, M.J.A. 1996. Canopy structure and nitrogen distribution in dominant and subordinate plants in a dense stand of Amaranthus dubius L. with a size hierarchy of individuals. Oecologia 105: 504-513.

Barnes, P.W., Beyschlag, W., Ryel, R., Flint, S.D. \& Caldwell, M.M. 1990. Plant competition for light analyzed with a multispecies canopy model. III. Influence of canopy structure in mixtures and monocultures of wheat and wild oat. Oecologia 82: 560-566. 
De Pury, D.G.G. \& Farquhar, G.D. 1997. Simple scaling of photosynthesis from leaves to canopies without the errors of big-leaf models. Plant Cell Environ. 20: 537-557.

Fliervoet, L.M. 1984. Canopy structure of Dutch grasslands. Ph.D. Thesis, Utrecht University, Utrecht, NL.

Givnish, T.J. 1982. On the adaptive significance of leaf height in forest herbs. Am. Nat. 120: 353-381.

Glenn-Lewin, D.C., Peet, R.K. \& Veblen, T.T. 1992. Plant succession. Theory and prediction. Chapman \& Hall, London, UK.

Hikosaka, K. \& Hirose, T. 1997. Leaf angle as a strategy for light competition: Optimal and evolutionarily stable lightextinction coefficient within a leaf canopy. Ecoscience 4: 501-507.

Hikosaka, K., Sudoh, S. \& Hirose, T. 1999. Light acquisition and use by individuals competing in a dense stand of an annual herb, Xanthium canadense. Oecologia 118: 388396.

Hirose, T. \& Werger, M.J.A. 1995. Canopy structure and photon flux partitioning among species in a herbaceous plant community. Ecology 76: 466-474.

Huber, H. 1996. Plasticity of internodes and petioles in prostrate and erect Potentilla species. Funct. Ecol. 10: 401-409.

Huber, H. 1997. Architectural plasticity of stoloniferous and erect herbs in response to light climate. Ph.D. Thesis, Utrecht University, Utrecht, NL.

Huber, H. \& Wiggerman, L. 1997. Shade avoidance in the clonal herb Trifolium fragiferum: a field study with experimentally manipulated vegetation height. Plant Ecol. 130: 53-62.

Huber, H., Fijan, A. \& During, H.J. 1998. A comparative study of spacer plasticity in erect and stoloniferous herbs. Oikos 81: 576-586.

Huston, M. \& Smith, T. 1987. Plant succession: life history and competition. Am. Nat. 130: 168-198.

Küppers, M. 1984. Carbon relations and competition between woody species in a Central European hedgerow. I. Photosynthetic characteristics. Oecologia 64: 332-343.

Küppers, M. 1985. Carbon relations and competition between woody species in a Central European hedgerow. IV. Growth form and partitioning. Oecologia 66: 343-352.

Leeflang, L., During, H.J. \& Werger, M.J.A. 1998. The role of petioles in light acquisition by Hydrocotyle vulgaris $\mathrm{L}$. in a vertical light gradient. Oecologia 117: 235-238.

Makino, T. 1962. New illustrated Flora of Japan. Hokuryukan, Tokyo, JP.

Miles, J. 1979. Vegetation dynamics. Chapman \& Hall, London, UK.

Mitchley, J. \& Willems, J.H. 1995. Vertical canopy structure of
Dutch chalk grasslands in relation to their management. Vegetatio 117: 17-27.

Miyawaki, A. 1987. The vegetation of Japan. Vol. 8. Tohoku. Shibundo Publishers, Tokyo, JP.

Monsi, M. \& Saeki, T. 1953. Ueber den Lichtfaktor in den Pflanzengesellschaften und seine Bedeutung fuer die Stoffproduktion. Jpn. J. Bot. 14: 22-52.

Nagashima, H., Terashima, I. \& Katoh, S. 1995. Effects of plant density on frequency distributions of plant height in Chenopodium album stands: analysis based on continuous monitoring of height growth of individual plants. Ann. Bot. 75: $173-180$.

Noble, I.R. \& Slatyer, R.O. 1980. The use of vital attributes to predict successional changes in plant communities subjected to recurrent disturbances. Vegetatio 43: 5-21.

Ohwi, J. 1965. Flora of Japan. Smithsonian Institution, Washington, DC.

Pearcy, R.W., Tumosa, N. \& Williams, K. 1981. Relationships between growth, photosynthesis and competitive interactions for a C3 and a C4 plant. Oecologia 48: 371-376.

Prach, K., Pyšek, P. \& Šmilauer, P. 1997. Changes in species traits during succession: a search for pattern. Oikos 79: 201205.

Schieving, F., Pons, T.L., Werger, M.J.A. \& Hirose, T. 1992. Vertical distribution of nitrogen and photosynthetic activity at different plant densities in Carex acutiformis. Plant Soil 142: 9-17.

Schmitt, J., Ehrhardt, D.W. \& Cheo, M. 1986. Light-dependent dominance and suppression in experimental radish populations. Ecology 67: 1502-1507.

Schwinning, S. \& Weiner, J. 1998. Mechanisms determining the degree of size asymmetry in competition among plants. Oecologia 113: 447-455.

Takatsuki, S. 1978. Precision of fecal analysis: a feeding experiment with penned sika deer. J. Mamm. Soc. Japan 7: 167180.

Takatsuki, S. 1980. Food habits of sika deer on Kinkazan Island. Sci. Rep. Tohoku Univ. Series IV (Biology) 38: 7-31.

Takatsuki, S., Suzuki, K. \& Suzuki, I. 1994. A mass-mortality of sika deer on Kinkazan Island, northern Japan. Ecol. Res. 9: 215-223.

Weiner, J. \& Thomas, S.C. 1986. Size variability and competition in plant monocultures. Oikos 47: 211-222.

Werger, M.J.A. \& Hirose, T. 1991. Leaf nitrogen distribution and whole canopy photosynthetic carbon gain in herbaceous stands. Vegetatio 97: 11-20.

Wilson, J.B. 1988. The effect of initial advantage on the course of plant competition. Oikos 51: 19-24.

Received 17 September 2001; Revision received 8 May 2002; Accepted 8 May 2002. Coordinating Editor: R.H. Marrs. 